THE JOURNAL OF THE SOCIETY OF CHEMICAL INDUSTRY, JAPAN.

Vol. XXVIII. October, $1925 . \quad$ No. 10.

ABSTRACTS FROM THE ORIGINAL PAPERS.

\title{
STUDIES ON CATALYTIC HYDROGENATION OF HIGHLY \\ UNSATURATED ACIDS. \\ PART I. ON THE COURSE OF HYDROGENATION OF METHYLESTER OF HIGHLY UNSATURATED ACIDS in THE PRESENCE OF NICKEL CATALYST.
}

By Yoshiyuki Toyama, Kögakushi and Tomotarō Tsuchiya.

(Received June ro, 1925)

Methylester of highly unsaturated acids has been hydrogenated in the presence of nickel catalyst at $185-210^{\circ} \mathrm{C}$ under ordinary pressure. Before the iodine value of original sample falls down to II.4, a portion of sample was taken out at 12 different stages of hydrogenation and each sample was analysed. The original sample used in this experiment was prepared from Japanese sardine oil. The oil was treated by means of sodium-soap-acetone method. A concentrated part of highly unsaturated acids obtained by this method was converted into methylester, the latter subjected to fractional distillation in vacuo and a fraction $210-227^{\circ} \mathrm{C}$ under $5 \mathrm{~mm}$. pressure was collected. It had the saponification value 169.2 and the iodine value (pyridine sulfate dibromide method) 350.6 ; the fatty acids obtained from the methylester yielded $127.1 \%$ of ether-insoluble bromide containing 71.06 $\% \mathrm{Br}$. The individual acids which may possibly be present in the original sample are among the following four acids:

$\mathrm{C}_{20} \mathrm{H}_{32} \mathrm{O}_{2}, \mathrm{C}_{22} \mathrm{H}_{34} \mathrm{O}_{2}, \mathrm{C}_{33} \mathrm{H}_{32} \mathrm{O}_{2}$, and $\mathrm{C}_{22} \mathrm{H}_{33} \mathrm{O}_{2}$.

The experimental results set forth in this paper are summarized as follows.

(I) The amount of the fatty acids giving ether-insoluble bromide steadily decreases with the progress of hydrogenation. Thus the fatty acids 
of the sample having an iodine value of r73. I yields only $1.67 \%$ of etherinsoluble bromide. The fatty acids of the sample having an iodine value of 134.9 yields no bromide insoluble in ether: As the Br-content of etherinsoluble bromide is found to be more than $69 \%$ in every case, no fatty acids giving ether-insoluble hexabromide can be formed in substantial amount duriag the entire course of hydrogenation. The fact that the br-content of ether-insoluble bromide decreases a little with the progress of hydrogenation may be accounted for by partial conversion of the fatty acids of five double bonds to those of four double bonds.

(2) Until nearly all of the fatty acids giving ether-insoluble bromide disappear, very little sclid acids are formed. Immediately after the almost complete disappearance of fatty acids giving ether-insoluble bromide, solid acids bigin to be formed in substantial amount. As it can reasonably be assumed that most of the fatty acids $\left(\mathrm{C}_{20}\right.$ and $\mathrm{C}_{2: 2}$ ) of one clouble bond formed during hydrogenation are solid acids, it appears that until nearly all of the fatty acids giving ether-insoluble bromide disappear hydrogenation results mainly in the conversion of highly unsaturated acids to acids of two double bonds. Immediately after the almost complete disappearance of fatty acids giving ether-insoluble bromide, the conversion of the acids of two double bonds to those of one double bond with the formation also of saturated acids takes place mainly. Even in the sample having an iodine value of I34.9, the presence of saturated acids is indicated.

(3) It was found that the solid acids of one double bond formed during hydrogenation contain those having markedly higher meiting points than naturally occurring $\mathrm{C}_{2 n}$ and $\mathrm{C}_{22}$ acids of oleic series. Even the presence of solid acids of two double bonds are indicated.

(The Tokyo Imperial Industrial Laboratory, Yoyohata near Tokyo.) 


\title{
UNTERSUCHUNGEN UBER DIE HYDRIERUNG DER FETTE. VI. MitTEILUNG.
}

\author{
Von G. Kita, Kögåkihaћushi, T. Mażume, Kōgakushi und K. Kino.
}

(Eingegangen am 16 . Juni r925)

Als Folge der früheren Mitteilung haben die Verfasser weiter die katalytische Wirkung von dem unter abweichenden Temperaturen bezw. Zeitdauern teilweise reduzicrten Nickeloxyd, Nickeloxyd selbst und auch von Nickelkarbonat untersucht und gefunden, dass sie alle sich wie die Katalysatoren in der früheren Mitteilung verhalten.

Versuche mit saurer Bleicherde und Silikagel nach Patrick als Katalysatoren und auch die mit saurer Ercle und Nickelkarbonat in Atmosphäre von Kohlensäure bezw. Stickstoff zeigen ähniiche Veränderungen der Jodzahlen, obwohl sie ganz schwach sind, so dass die oben genannten Wirkungen ausser der Hydrierung und Dehydrierung etwas kompliziert sein müssen. Weiteres wird bald folgen.

\section{ON THE HYDROGENATION OF THE ISOMERIC SYSTEM OF THE UNSATURATED FATTY ACIDS.}

\section{By Sei-ichi Ueno. \\ (Received June 6, 1925.)}

Comparative hydrogenation of the isomerides of some unsaturated fatty acids was investigated with platinum black in ethereal and acetic acid media, and the following results were obtained:

(I) In the hydrogenation of elaidic and oleic acids, the former was easily hydrogenated than the latter.

(2) In the case of linolic acid group, hydrogen absorption of linolic acid was most rapid, while $\beta$-eleostearic acid was more than $\alpha$-eleostearic acid.

(3) It was found that the hydrogenation velocity of the unsaturated acids is remarkably related to the constitution of the molecule. 


\title{
ON THE INFLUENCE OF SOME SUBSTANCES TO THE DEPOI- SONING ACTION OF JAPANESE ACID CLAY TO THE PATTY OILS POR HARDENING.
}

\author{
By Sei-ichi Ueno and Zensaku Okamura.
}

(Received June 6, 1925.)

Numerous experiments on the depoisoning action of Japanese acid clay were carried out, using sardine oil and the hardening tests were made with nickel catalyst to determine the poisons remained in the refined sardine oil.

The following conclusion was given :

(I) The depoisoning action of the acid clay was seemed, in many cases، to have no relation to the bleaching action.

(2) The depoisoning action of the acid clay was activated by the presence of calcium carbonate and aluminium hydroxide.

\section{ON THE ARTIFICIAL BEEF TALLOW. (PART I). COMPOSITION OF THE FATTY ACIDS OF HYDROGENATED SOYA BEAN OILS. \\ By Masawo Hirose. \\ (Received June 7, 1925.)}

The author gives a definition to the artificial beef tallow something like this: It is the fat produced by chemical change artificially or by mixing other fatty oils with the such artificial product.

He tried an analysis of I I samples of soya bean oil which has been on the progress of hydrogenation in commercial scale with $\mathrm{Ni}$ catalyser. Analytical methods used in this research were the distillation of methyl ester, fractional crystallization, separation of saturated and unsaturated acids by $\mathrm{Pb}$ salt ether method, separation by means of the bromo-derivatives of liquid fatty acids, calculation from iodine v. etc., and the analytical results were as follows :- 
Characteristics of hydrogenated soya bean oils and the mixed fatty acids from them.

Hydrogenated oils

\begin{tabular}{|c|c|c|c|c|c|c|}
\hline $\begin{array}{l}\text { Time in } \\
\text { hydrogenation } \\
\text { (Hour) }\end{array}$ & Melting pt. $\left(\mathrm{C}^{\circ}\right)$ & Iodine $\mathrm{v}$. & Sap. v. & Melting pt. $\left(\mathrm{C}^{\circ}\right)$ & Iodine $\mathbf{v}$. & $\begin{array}{r}\text { Neutrali } \\
\mathbf{v} .\end{array}$ \\
\hline O-iginal oil & $\begin{array}{c}\text { Transparent } \\
\text { liquid. }\end{array}$ & 135.5 & 192.4 & Semi solid & 140.2 & 201.6 \\
\hline $\mathbf{I}$ & $\begin{array}{l}\text { Small part } \\
\text { solid }\end{array}$ & 112.7 & & $"$ & $117 \cdot 5$ & 201.0 \\
\hline 2 & $"$ & $97 \cdot 3$ & & $"$ & Ior.7 & 200.1 \\
\hline 3 & Semi solid & $87 \cdot 5$ & & 36 & 90.0 & 200.0 \\
\hline 4 & $42-49 \cdot 5$ & 82.1 & & 37 & $84 \cdot 7$ & 200.0 \\
\hline 5 & $45-50.5$ & 69.1 & 190.2 & $4^{2 \cdot 5}$ & 72.4 & 199.8 \\
\hline 6 & $47-53$ & 60.2 & & $49 \cdot 5$ & 63.5 & 199.7 \\
\hline 7 & $55-57$ & 52.8 & & 52.5 & $54 \cdot 3$ & $199 \cdot 5$ \\
\hline 8 & $5^{8-59 \cdot 5}$ & $44 \cdot 4$ & & 55.5 & $45 \cdot I$ & 1996 \\
\hline 9 & $61.5-62.5$ & $35 \cdot 0$ & & $5^{8.0}$ & $37 \cdot 4$ & 199.2 \\
\hline Special & $67.5-68.0$ & 1.8 & 189.5 & $6 j-66.1$ & $* 1 \cdot 3$ & * 200.2 \\
\hline
\end{tabular}

* Unsaponifiable matter was removed.

Composition of the fatty acids of hydrogenated soya bean oils in the above table.

\begin{tabular}{|c|c|c|c|c|c|c|}
\hline $\begin{array}{l}\text { Time in hydro- } \\
\text { genation (Hlour) }\end{array}$ & $\begin{array}{l}\text { Linolenic } \\
\text { acid (\%) }\end{array}$ & $\begin{array}{l}\text { Linolic } \\
\text { acid (\%) }\end{array}$ & $\begin{array}{c}\text { Oleic } \\
\text { acid }(\%)\end{array}$ & $\begin{array}{l}\text { Containing iso-oleic } \\
\text { acid in round number. }\end{array}$ & $\begin{array}{l}\text { Stearic } \\
\text { acid }(\%)\end{array}$ & $\begin{array}{l}\text { Palmitic } \\
\text { acid (\%) }\end{array}$ \\
\hline Original oil & 4.63 & 57.83 & 25.13 & - & ? & 12.4 \\
\hline$x$ & 0.42 & 39.82 & 42.76 & 5 & 4.60 & 12.4 \\
\hline 2 & $\ldots$ & 24.05 & 58.18 & 13 & $5 \cdot 36$ & 12.4 \\
\hline 3 & - & 11.80 & 69.65 & 19 & 6.26 & 12.4 \\
\hline 4 & - & 9.16 & 72.80 & $2 I$ & $5.65 ?$ & 12.4 \\
\hline 5 & - & 4.46 & 69.01 & 30 & 14.15 & $\mathbf{1} 2.4$ \\
\hline 6 & - & 2.62 & $64 \cdot 76$ & 32 & $20.3 x$ & $\mathbf{1 2 . 3}$ \\
\hline 7 & - & - & 60.27 & 25 & 27.43 & 12.3 \\
\hline 8 & - & - & 50.06 & 28 & 37.64 & $12 \cdot 3$ \\
\hline 9 & - & - & $4 I .5 I$ & 20 & 46.19 & I2.3 \\
\hline Special & - & - & I.44 & - & 86.36 & 12.27 \\
\hline
\end{tabular}

The author points out the following facts:

I. The varieties of fatty acids of moderately hydrogenated soya bean oil is the same as that of beef tallow, only differs in the percentage of palmitine and the presence of iso-olein in hy-drogenated oil, but the hardened 
soya bean oil is very favourable as a substitute of beef tallow in the poiut of view of soap making.

2. Good artificial beef tallow is obtained by mixing hydrogenated soya

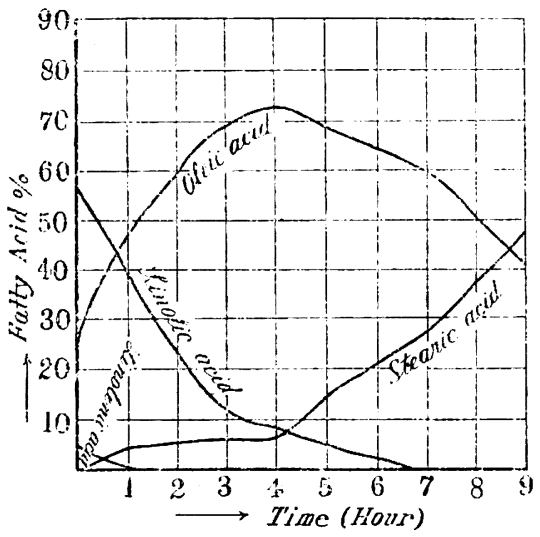
bean oil (I. v. 53) with refined Japan wax or Chinese vegetable tallow ( $5-20 \%$ ).

3. The hydrogenation of soya bean oil is the important process of oleine rnanufacture, not to speak of stearin. The reason is clearly explained in the table and the figure.

4. The separation of the substitute of olive and Tsubaki oil is very likely possible from moderately hydrogenated oils.

5. Melting point of the mixed fatty acids are lower than that of original hydrogenated oils. Natural oils and fats are in the opposition.

6. A very small quantity of artificial petroleum is produced in the technical hydrogenation of oils at the temperature $190-200^{\circ} \mathrm{C}$ using $\mathrm{Ni}$ catalyser.

7. Composition of soya bean oil shown by Matthes and Dahle do not agree to the iodine value of soya bean oil produced in the East, because the contents of linolic acid are too small.

(The Tokyo Imperial Industrial Laboratory.)

\section{ON THE MEDIUM IN WHICH TUNG OIL DRIES IN WEBBED APPEARANCE.}

\section{By Tsunetarō Sakami, Kōgakushii.}

(Received June 12, 1925.)

It is well known that Tung oil dries giving a white, opaque and webbed film. But the study on the medium in which it dries in the above appearance is not yet satisfactory. 
The author being suggested by a marked effect of the medium on the state of the dried film studied to find the condition to cause the webbing and whitening, and has reached the result as follows:

(1) The film of the tung oil varnish webs and whitens with radiating crystalline appearance when it dries in a place in which some fuel is burned.

(2) The temparature $\left(10^{\circ} \sim 60^{\circ} \mathrm{C}\right)$ and the moisture changes due to the combution have no effect on the webbing and whitening.

(3) The contact of the combustion gas to the not yet dried film causes the webbing and whitening.

(4) The intencity of the light has no effect.

(5) Strong wind carries the combustion gas to a remort place where we often anexpectedly find the tung oil varnish web and whiten; and the draft test of sparvarnish means the concentration of probability of the contract of the combustion gas to the test plate.

(6) $\mathrm{CO}_{2}$, $\mathrm{CO}$ and $\mathrm{H}_{2} \mathrm{O}$ which are commonly considered as the components of the combustion gas have no effect on the webbing and whitening.

(7) The weight increase of tung oil on drying was measured both in the air containing the combustion gas and in that not containing it, and the fact was found that in the former the weight increase was greatly accelcrated, which suggested that the combustion gas should contain some oxidising catalizer.

(S) In the literatures it is already known that by the combustion of coal gas \& etc. traces of $\mathrm{O}_{3}, \mathrm{H}_{2} \mathrm{O}_{2}$ and $\mathrm{NO}_{2}$ are produced; and the existence of the oxidising catalizer in the combustion gas was confirmed by the reaction of $\mathrm{KI}$ and starch paper as the indicator.

(9) $\mathrm{By} \mathrm{O}_{3}^{\prime}$ the webbing and whitening were caused when it occurred in considerable amount.

(IO) By $\mathrm{H}_{2} \mathrm{O}_{2}$ the webbing and whitening were not observed.

(I I) By $\mathrm{NO}_{2}$ the webbing and whitening were caused very keenly;

One pt. of $\mathrm{NO}_{2}$ in $\mathrm{I}, 000,000$ pts. of air was enough to cause the webbing as sharply as the combustion gas; and it is concluded that the webbing caused by the contact of the combustion gas is due to the rapid and uuseen solidification of the outer layer of the film by the catalytic oxidation of 
$\mathrm{NO}_{2}$ (probably not $\mathrm{O}_{3}$ nor $\mathrm{H}_{2} \mathrm{O}_{2}$ ) trace of which occurs by the combustino of common fuels.

(12) $\mathrm{SO}_{2}$ or $\mathrm{Cl}_{2}$ has no effect on webbing and whitening.

(13) High percentage of $\mathrm{O}_{2}$ in the air $(90 \%)$ has no effect.

(14) Tung oil dries without giving the webbed nor whitened film, but a plain and transparent one like that of linseed oil, if it dries in the air completely free from oxidising catalytic gases.

(The Labolatory of Kwansai Paint Co. Ltd.)

\section{ON NAPHTHENIC SOAP.}

\section{By Jirō Mikumo, Kögakushi.}

(Received June 3, 1925.)

Na-soap prepared from a sample of Japanese naphthenic acids $\left(\mathrm{d}_{4^{\circ}}^{19}=\right.$ 0.9708 , acid value $=249.2$ ) was examined for its soap characters, i. e., (I) surface tension, (2) interfacial tension and emulsifying power, (3) lathering power, and (4) detergent power. For comparison parallel tests were done with Na-soaps from Kahlbaum's oleic acid, cocoa nut oil and rosin.

(I) Surface tension (dynes $/ \mathrm{cm}$ ), by a Traube's stalagmometer.

\begin{tabular}{lccccccc}
\multicolumn{1}{c}{ soaps } & \multicolumn{2}{c}{ conc. $1 \%$} & \multicolumn{2}{c}{ conc. $25 \%$} \\
Naphthenate & $20^{\circ} \mathrm{C}$ & $40^{\circ} \mathrm{C}$ & $20^{\circ} \mathrm{C}$ & $40^{\circ} \mathrm{C}$ & & $20^{\circ} \mathrm{C}$ & $4^{\circ} \mathrm{C}$ \\
Oleate & 27.3 & 26.6 & 26.6 & 26.0 & 29.3 & 28.4 \\
Coconate & 27.5 & 26.9 & 25.8 & 25.7 & 24.9 & 24.8 \\
Rosinate & 30.9 & 26.7 & 28.7 & 24.0 & 30.9 & 24.8 \\
& 33.8 & 33.5 & 36.8 & 35.9 & 42.0 & 41.3
\end{tabular}

(2) Relative interfacial tension (drop number), by Hillyer's drop-pipette against a fraction (b.p. I $50-200^{\circ}$ ) of kerosene ("Tiger" brand of Standard Oil Co.). 


\begin{tabular}{|c|c|c|c|c|c|c|c|c|}
\hline \multirow{2}{*}{ soaps } & \multicolumn{2}{|c|}{ cor.c. $1 \%$} & \multicolumn{2}{|c|}{ conc. $0.5 \%$} & \multicolumn{2}{|c|}{ corc. $0.25 \%$} & \multicolumn{2}{|c|}{0 (=water $)$} \\
\hline & $20^{\circ} \mathrm{C}$ & $40^{\circ} \mathrm{C}$ & $20^{\circ} \mathrm{C}$ & $40^{\circ} \mathrm{C}$ & $20^{\circ} \mathrm{C}$ & $40^{\circ} \mathrm{C}$ & $20^{\circ} \mathrm{C}$ & $40^{\circ} \mathrm{C}$ \\
\hline Naphthenate & I3I & 127 & 57 & 56 & 29 & 28 & 10.5 & II \\
\hline Oleate & 195 & 197 & 133 & 126 & 87 & 83 & $"$ & $"$ \\
\hline Coconate & .- & 188 & (98) & I 21 & 63 & 66 & " & $" \prime$ \\
\hline Rosinate & 126 & 120 & $6 I$ & 63 & 37 & 36 & $"$ & $"$ \\
\hline
\end{tabular}

Emulsions were prepared by shaking soap solutions and kerosene in 2 stoppered cylinders of the same shape $\left(40^{\circ} \mathrm{C}\right)$. Emulsifying power as expressed by the volume ratio of oil : water in the middle permanent emulsion (=" cream") ivas proved to go parallel to drop numbers of Hillyer's.

(3) Lathering power $\left(20^{\circ}, 40^{\circ}\right)$ was measured with a lathering flask of Stiepel's type in a thermostat. Lathering power of naphthenate is not great in Stiepel's sense of "lather value", but the volume of lather is most copious-thin, fine and vanishing-even more than coconate.

(4) Detergent power was compared by actual washing with Heermann's method somewhat modified at $40^{\circ}$.

Detergent order: Coconate, oleate, naphthenate, rosinate. Naphthenate is by far poorer than oleate in washing activity.

Naphthene soap stands between fatty soap and rosin soap.

\section{THE CATALYTIC OXIDATION OF HYDROCYANIC ACID (III.) OXIDATION OF HCN USING OXIDES OF BASE METALS AS CATALYSERS.}

By Heima Sinozaki, Kögakushi and Ryōsaburō Hara, Kōgakuhakushi.

(Received June 6, 1925.)

I. In the first and second reports the authors reported that, $\mathrm{HCN}$ can be as easily oxidized as ammonia into NO with air when Pt-net is used as a catalyser. They continued the study of catalytic oxidation of $\mathrm{HCN}$ using the following substances as catalysers, porcelain and silica granules, platinized asbestos, $\mathrm{Fe}_{2} \mathrm{O}_{3}, \mathrm{Fe}_{2} \mathrm{O}_{3}+\mathrm{Bi}_{2} \mathrm{O}_{3}, \mathrm{Co}_{3} \mathrm{O}_{4}(?), \mathrm{Co}_{3} \mathrm{O}_{4}+\mathrm{Bi}_{2} \mathrm{O}_{3}, \mathrm{CuO}, \mathrm{Cr}_{2} \mathrm{O}_{3}, \mathrm{NiO}$, 
$\mathrm{Mn}_{2} \mathrm{O}_{3}, \mathrm{MnO}_{2}+\mathrm{CuO}$, and observed that each catalyser has considerable catalytic power except silica and porcelain among which $\mathrm{Fe}_{2} \mathrm{O}_{3}+\mathrm{Bi}_{2} \mathrm{O}_{3}, \mathrm{CO}_{2} \mathrm{O}_{4}$, $\mathrm{Co}_{3} \mathrm{O}_{4}+\mathrm{Bi}_{2} \mathrm{O}_{3}$, and $\mathrm{MnO}+\mathrm{CuO}$ are almost equally effective as $\mathrm{Pt}$-net.

II. The phenomenon of activation was also observed with metal oxides as in the case of Pt-net, and when activated, the yield of NO increases in many cases especially at relatively low temperatures.

III. The curves which express the relation between the $\mathrm{HCN}$ concentration and the yield of $\mathrm{NO}$ at $600^{\circ} \mathrm{C}$ and $700^{\circ} \mathrm{C}$ were found to be very similar in both cases of $\mathrm{Fe}_{2} \mathrm{O}_{3}+\mathrm{Bi}_{2} \mathrm{O}_{3}$ and platinum net as catalysers. This fact proves that the reaction mechanism is identical in both cases.

IV. The curves which express the relation between the yield of NO and the time of contact of the reacting gases with the catalyser were drawn and the properties of several catalysers were compared.

\section{PLATINUM AS CATALYST fOR AMMONIA OXIDATION. By Shun-ichi Uchida, Kögakushi.}

(Received June, 5. I925.)

I) In the previous report on the base metal catalysts, the author considered the catalytic oxidation of ammonia from a new standpoint, and derived an expression which shows that this reaction is a consecutive one consisting of two reactions of the first order.

In this report the author proved the same by using platinum gauze of 1369 mesh per sq. $\mathrm{cm}$ as catalyser. The rate of oxidation can be expressed by

$$
\eta=-\mathrm{r} .0054\left(\mathrm{e}^{-5.725 \mathrm{t}}-\mathrm{e}^{-0.0314 \mathrm{t}}\right) \mathrm{t}=1 \mathrm{O}^{-3} \mathrm{sec} .
$$

The following table shows the yield in nitric oxide calculated by this expression as compared with the observed values. 


\begin{tabular}{|c|c|c|}
\hline Time of contact & & \\
\hline in $10^{-3} \mathrm{sec}$. & calc. & olls. \\
\hline 0.1 & $43.5 \%$ & - \\
\hline 0.2 & 63.3 & $\cdots$ \\
\hline 0.4 & 89.1 & $\cdots$ \\
\hline 05 & 93.2 & -- \\
\hline 0.63 & $9^{6.4}$ & $96.1 \%$ \\
\hline 0.9 & 97.0 & --. \\
\hline 0.87 & $97 \cdot 2(-)$ & $97 \cdot 3$ \\
\hline 0.92 & $97 \cdot 2(+)$ & - \\
\hline 1.00 & 97.1 & - \\
\hline I.24 & $\dot{a} 6.6$ & 96.4 \\
\hline I.5O & 95.9 & 95.2 \\
\hline 2.00 & $94 \cdot 4$ & $94 \cdot 5$ \\
\hline 3.00 & 91.5 & - \\
\hline
\end{tabular}

2) The velocity constant of the primary reaction for the platinum catalyst is $2 S$ times greater than that for the base metal catalyst, and the constant for the secondary reaction for the former catalyst is 27 times greater than that for the latter. The highest yield calculated from theory is, $97.2 \%$ and the most effective time of contact corresponding to the highest yield is 0.00092 second.

3) During the catalytic action platinum evaporates very slowly. The evaporated platinum that has deposited on the hot surface of the porcelain wall, acts as a catalyst for the decomposition of nitric oxide formed by the primary reaction, and thus reduces the yield in nitric oxide. For this reason the porcelain combustion tube which contains catalyst and a part of the glass connection were renewed at every experiment, and the mean of the first two or three determinations was taken as the correct value. This phenomenon of vaporization of platinum seems to be a manifestation of the violent motions of platinum atoms during the catalysis which also causes the transformation of the smooth surface of the metal into the rough activated state. Action of platinum as a nitric oxide decomposing catalyst even at a comparatively low temperature (at $600^{\circ} \mathrm{C}$ or less) was already observed by Jellinek (Z. anorg. Chem., Igo6 49, 249).

4) A comparison of platinum catalyst and the base metal catalyst is given. (The Fixed Nitrogen Laboratory, Meguro, Tokyo.) 


\title{
NEW SCHREIB'S PROCESS FOR AMMONIA SODA MANUFACTURE.
}

\author{
By Mototarō Matsui, Kögakuhakushi, Takeo Sekiyama, \\ Kögakushi and Kaoru Watanabe, Kögakushi.
}

(Received May 29, 1925.)

Summary.

I. The distillation method would not succeed in determination of free ammonia because of the reversible reaction in the following chemical equation;

$\mathrm{NaCl}+\mathrm{NH}_{4} \mathrm{HCO}_{3} \rightleftarrows \mathrm{NH}_{4} \mathrm{Cl}+\mathrm{NaHCO}_{3}$

The authors however could calculate the constituents in the mother liquor by alcoholic method or from solubilities of $\mathrm{NaHCO}_{3}$ and $\mathrm{NH}_{4} \mathrm{HCO}_{3}$.

2. The authors have studied the so called New Screib's process on cooling the mother liquor after the addition of $\mathrm{NaCl}$.

\section{Solution}

cooled at $5^{\circ} \mathrm{C}$ g. per $\mathrm{L}$.
Solution

cooled at $0^{\circ} \mathrm{C}$ g. per L.

$\begin{array}{lcc}\mathrm{NH}_{4} \mathrm{Cl} & 127.0 & 104.7 \\ \mathrm{NaCl} & 198.8 & 230.2 \\ \mathrm{NH}_{4} \mathrm{HCO}_{3} & 32.08 & 15.62 \\ \mathrm{NaHCO}_{3} & 14.18 & 6.9 \\ \mathrm{NH}_{4} \mathrm{OH} & 12.98 & 12.37\end{array}$

3. From the stand point of the phase rule, the authors have graphically studied New Schreib's process and found its position near the congruently saturated point. For this reason Schreib's figure ought to be amended.

4. From the experimental results this process was technically discussed. (May, 1925, Technical Chemical Laboratory, Waseda University.) 


\title{
ON THE CONDENSATION PRODUCTS OF PHENOLS AND ALDEHYDES. PART I. INFLUENCES OF AMMONIA UPON CONDENSATION OF PHENOL AND PORMALDEHYDE.
}

\author{
By Tadae Shōno, Kögakushi.
}

(Received May 26, 1925.)

The author investigated and studied influences of ammonia upon condensation of phenol and formaldehyde and fuund several points on which no satisfactory description has hitherto been put forth.

(I) The increase in the amount of ammonia used as a catalyser in the condensation of phenol and formaldehyde greatly increases the amount of the condensation product formed.

(2) The colour of the condensation product is deep yellow at ordinary condition and the greater is the amount of ammonia, the lighter is the colour of the condensation product.

(3) The colour of the final condensation product produced by using ammonia as a catalyser in the absence of air is not deep yellow but nearly colourless.

(4) The ordinary yellow-coloured condensation product produced by using ammonia as a catalyser fades at high temperature, and moreover the velocity of fading is, in the absence of air, greater in case of high temperature than comparatively low temperature. 